\title{
A new species of the genus Stenaelurillus Simon, 1885 (Araneae: Salticidae) from Vietnam
}

\author{
Dmitri V. Logunov \\ The Manchester Museum, The University of Manchester, Oxford Road, Manchester M13 9PL, UK \\ E-mail: dmitri.v.logunov@manchester.ac.uk
}

Abstract - A new species Stenaelurillus abramovi sp.nov. (`우) is described from Vietnam.

Key words - Spiders, description, Vietnam.

\section{Introduction}

The Salticidae fauna of Vietnam is known to number 103 species of 50 genera (Żabka, 1985; Logunov, 2001a; Peng \& Li, 2003; Sác et al., 2004). In the present paper a new species of Stenaelurillus Simon, 1885 collected from southern Vietnam (Province Ba Ria-Vung Tau) is described. The genus Stenaelurillus contains 22 valid species, mostly from Africa (Platnick, 2008), and it is its first record from Vietnam. The terminology and format of the description follows Logunov (2001b). The type specimens are shared between the Zoological Museum of the Moscow State University, Moscow, Russia (ZMUM; Dr K.G. Mikhailov) and Naturmuseum und Forschungsinstitut Senckenberg, Frankfurt am Main, Germany (SMFM; Dr P. Jäger).

\section{Description}

Stenaelurillus abramovi sp.nov.

(Figs. 1-7)

Type material. The o holotype (ZMUM) from Vietnam, Ba Ria-Vung Tau Province, Binh Chau-Phuoc Buu Nature

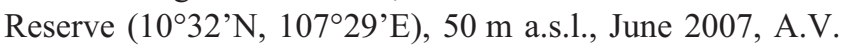
Abramov (expedition of the Joint Vietnam-Russian Tropical Centre).

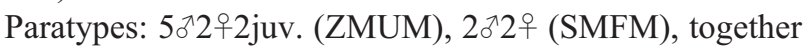
with the holotype.

Etymology. The species is dedicated to my friend and colleague, Dr Alexei V. Abramov (St.Petersburg, Russia), who collected the type series.

Diagnosis. Stenaelurillus abramovi sp.nov. is most closely related to $S$. hainanensis Peng, 1995 described and known only from Hainan Province of China (Peng, 1995). Both species possess the well-developed ventral tibial apophysis (arrowed on Fig. 2; see also Peng, 1995: fig. 10), the feature being not known in other described species of Stenaelurillus, except for S. triguttatus Simon, 1885 from Tibet (see Prószyński, 1984: 138). The new species can easily be distinguished from $S$. hainanensis by the shape and comparative sizes both of the emboli and of the terminal apophyses in males (cf. Fig. 1 and fig. 10 in Peng, 1995) and by the relative position of the copulatory pores and the epigynal pocket in females (cf. Fig. 4 and fig. 7 in Peng, 1995).

Distribution. The type locality only.

Habitat. Dry decidous dipterocarp forest on sands, changing into a more sparse forest consisted of Meloleucatrees (see Fig. 8). S. abramovi occurs on the litter of dipterocarp and other deciduous trees.

Description. MALE (holotype, Figs. 1-3, 6). Measurements. Carapace 2.43 long, 1.85 wide, 1.40 high at PLE. Ocular area 1.14 long, 1.53 wide anteriorly and 1.50 wide posteriorly. Diameter of AME 0.45. Abdomen 2.50 long, 1.83 wide. Chelicera length 0.70. Clypeus height 0.13 . Length of leg segments: I $1.33+0.60+0.80+0.63+0.43$; II $1.28+0.60+0.73+0.65+0.38$; III $1.85+0.95+1.10+$ $1.25+0.54 ; \quad$ IV $1.58+0.70+0.93+1.33+0.55$. Leg spination. Leg I: Fm d 0-1-1-4; Pt pr 0-1-0; Tb pr 1-1, v 12-2ap; Mt pr 1-1ap, v 2-2ap. Leg II: Fm d 0-1-2-5; Pt pr 01-0; Tb pr 1-1, rt 0-1, v 1-1-2ap; Mt pr 1-1ap, v 2-2ap. Leg III: Fm d 0-1-3-5; Pt pr and rt 0-1-0; Tb d 1-0, pr 1-1-1, rt 1-1-1-1, v 1-2ap; Mt d 1-1, pr and rt 1-0-2ap, v 0-2-2ap. Leg IV: Fm d 0-1-2-4; Pt pr and rt 0-1-0; Tb d 1-0, pr 1-1-1, rt 1-1-1-1, v 1-0-2ap; Mt d 1-0, pr and rt 1-1-2ap, v 0-2-2ap. Coloration. Carapace brown, with black veins. Eye field black, covered with whitish scales (Fig. 6). Clypeus brown; both clypeus and 'cheeks' densely covered with long yellow hairs. Sternum brownish, covered with white hairs. Maxillae and labium light yellow. Abdomen: dorsum and sides brown, venter light yellow; dorsum without a marked colour pattern, with large scutum covering $2 / 3$ of the dorsum length (Fig. 6). Book-lung covers yellow. Spinnerets long, their basal segments yellow, distal ones brown to dark brown. All legs: coxae and femora yellow; patellae, tibiae and metatarsus brown with dark brown to black patches and stripes; tarsi I black, tarsi II-IV yellow. 

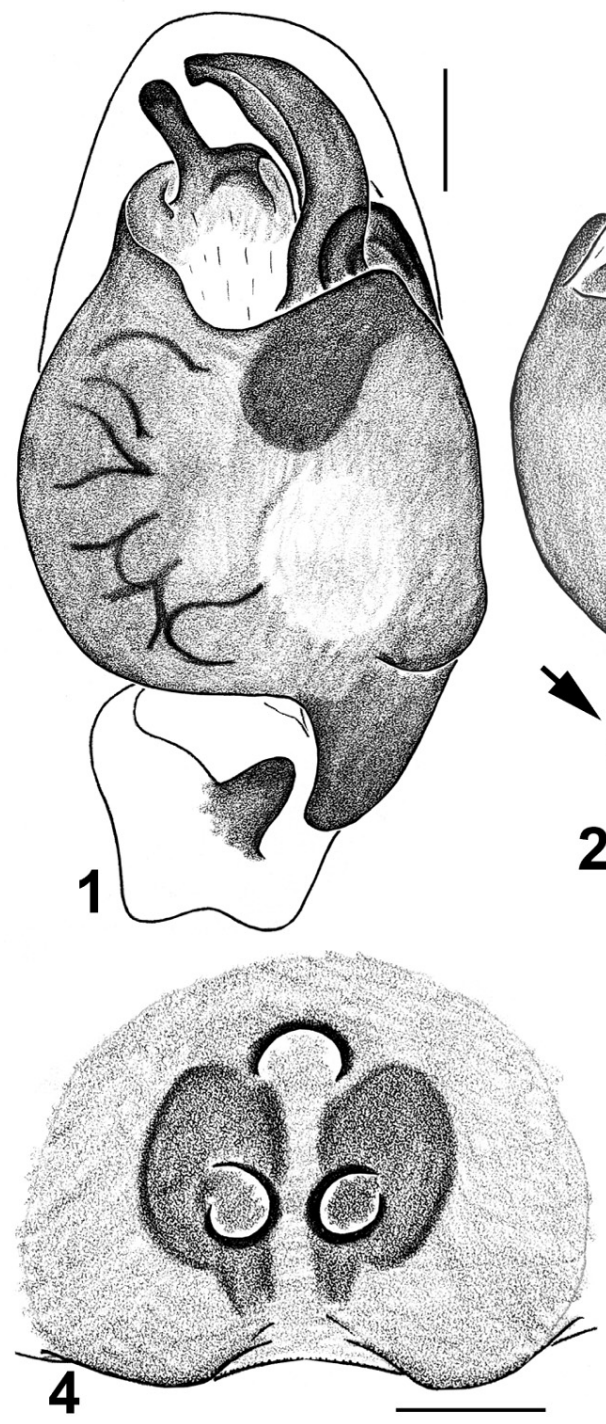
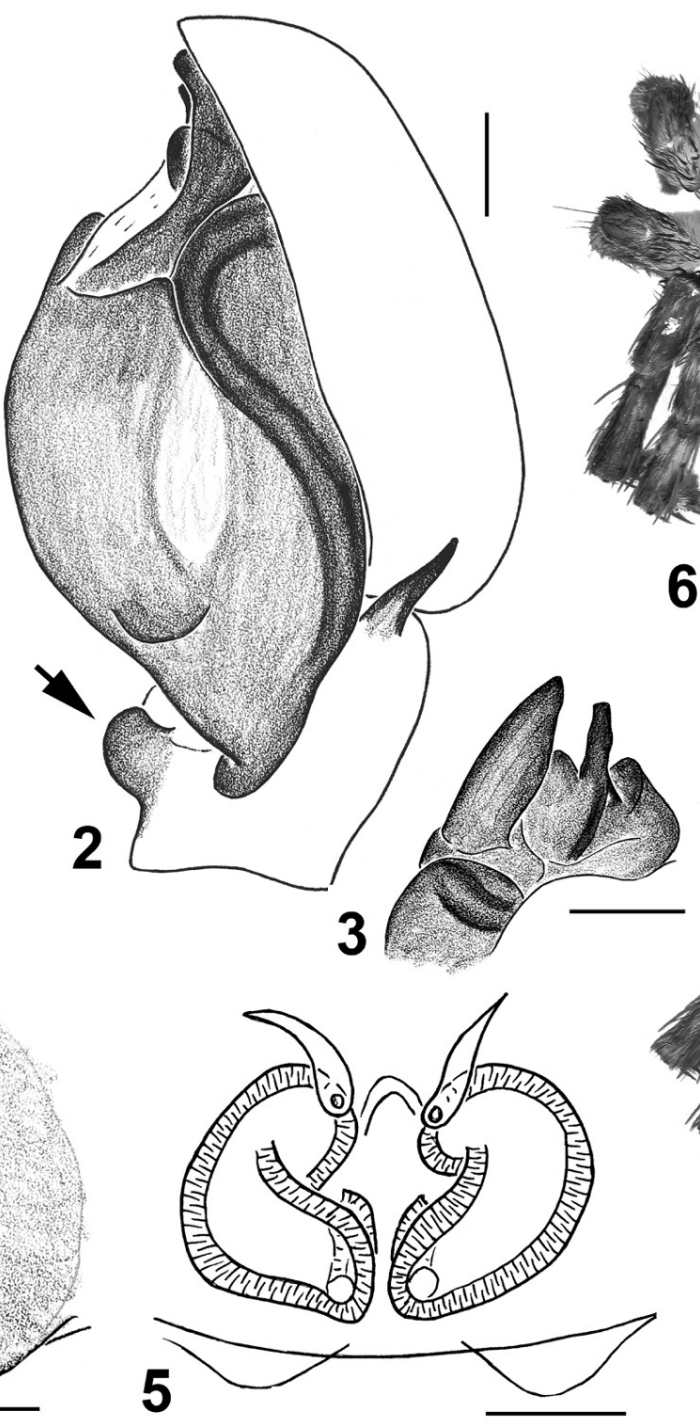
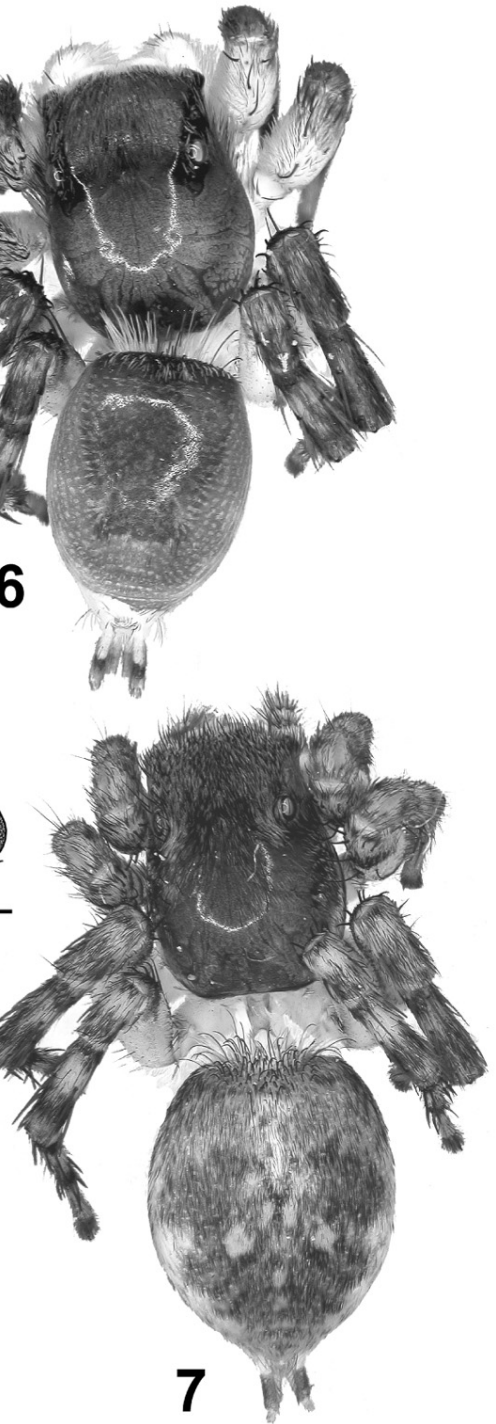

Figs. 1-7. Copulatory organs and general appearances of Stenaelurillus abramovi sp. nov. (paratypes). - 1, Male palp, ventral view; 2, ditto, retrolateral view; 3, the embolic division, dorsal view; 4, epigyne, ventral view; 5, spermathecae, dorsal view; 6, male, dorsal view; 7, female, dorsal view. Scale bars: $0.1 \mathrm{~mm}$.

Patellae, tibiae and metatarsi I darker (black) than remaining leg segments. Palps yellow, with brownish bulbus and cymbium, their femora densely covered with long yellow hairs. Palpal structure as in Figs. 1-3.

FEMALE (paratype, Figs. 4-7). Measurements. Carapace 2.73 long, 2.08 wide, 1.63 high at PLE. Ocular area 1.23 long, 1.63 wide anteriorly and 1.60 wide posteriorly. Diameter of AME 0.48. Abdomen 3.40 long, 2.63 wide. Chelicera length 0.75 . Clypeus height 0.25 . Length of leg segments: I $1.38+0.63+0.75+0.63+0.40$; II $1.45+0.68+0.75+0.58+0.50$; III $2.08+1.05+1.23+$ $1.40+0.55 ; \quad$ IV $1.83+0.83+1.15+1.50+0.60 . \quad$ Leg spination. Leg I: Fm d 0-1-1-5; Pt pr 0-1-0; Tb pr 1-1, v 12-2ap; Mt pr 1-1ap, v 2-2ap. Leg II: Fm d 0-1-2-5; Pt pr 01-0; Tb pr 1-1, v 1-1-2ap; Mt pr 1-1ap, v 2-2ap. Leg III: Fm d 1-2-5; Pt pr and rt 0-1-0; Tb d 1-0, pr and rt 1-2, v 1-0- 2ap; Mt d 1-1, pr and rt 1-0-2ap, v 0-1-2ap. Leg IV: Fm d $0-1-1-5 ;$ Pt pr and rt 0-1-0; Tb d 1-0, pr 1-1-1-1, rt 1-1-1, v 1-0-2ap; Mt d 1-1, pr 1-1-2ap, rt 1-0-2ap, v 1-1-2ap. Coloration as in the male, but differs as follows: eye field more densely covered with whitish scales (Fig. 7) and its front part covered with black protruding bristles; clypeus and palps without a cover of yellow hairs; all legs yellow, with patches of dark brown scales; dorsum without scutum, but with a poorly marked pattern of yellow spots (Fig. 7); and spinnerets are evenly brownish yellow. Epigyne and spermathecae as in Figs. 4, 5.

\section{Acknowledgments}

I wish to express my warmest thanks to Dr. Alexei V. Abramov of the Zoological Institute (St. Petersburg, Russia) for giving access to his spider materials from Vietnam collected during the expedition 


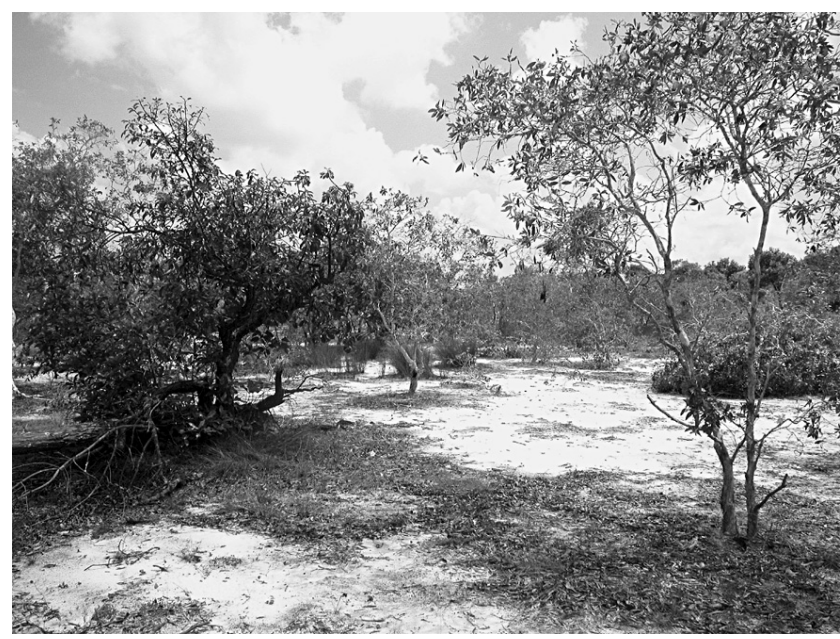

Fig. 8. The dry decidous dipterocarp forest on sands from where Stenaelurillus abramovi sp. nov. was collected (courtesy by A.V. Abramov).

organized and sponsored by the Joint Vietnam-Russian Tropical Research and Technological Centre (Hanoi).

\section{References}

Logunov, D. V. 2001a (for 2000). A redefinition of the genera Bianor Peckham \& Peckham, 1885 and Harmochirus Simon, 1885, with the establishment of a new genus Sibianor gen. n. (Aranei: Salticidae). Arthropoda Selecta 9(4): 221-286.

Logunov, D. V. 2001b. New and poorly known species of the jumping spiders (Aranei: Salticidae) from Afghanistan, Iran and Crete. Arthropoda Selecta 10(1): 59-66.

Peng, X. J. 1995. [Two new species of jumping spiders from China]. Acta Zootaxonomica Sinica 20(1): 35-38 [in Chinese, with English abstract].

Peng, X. J. \& Li, S. Q. 2003. New localities and one new species of jumping spiders (Araneae: Salticidae) from northern Vietnam. The Raffles Bulletin of Zoology 51(1): 21-24.

Platnick, N. I. 2008. The World Spider Catalog, Version 8.5 (the Salticidae page last updated, December 30 2007); online at $<\mathrm{http}$ :// research.amnh.org/entomology/spiders/catalog/INTRO1.html.>

Prószyński, J. 1984. Atlas rysunków diagnostycznych mniej znanych Salticidae (Araneae). Wyzsza Szkola Rolniczo-Pedagogiczna, Siedlcach 2: 1-177.

Sác, P. D., Côn, V. Q. \& Żabka, M. 2004. [A preliminary checklist of the jumping spiders (Araneae, Salticidae) of Vietnam]. Journal of Biology 26(3A): 48-56 [in Vientnamese].

Żabka, M. 1985. Systematic and zoogeographic study on the family Salticidae (Araneae) from Viet-Nam. Annales Zoologici, Polska Academia Nauk 39(11): 197-485.

Received February 21, 2008 / Accepted May 12, 2008 